\title{
PENGARUH METODE STRUKTUR ANALITIK SINTETIK (SAS) TERHADAP KEMAMPUAN MEMBACA PERMULAAN KELAS I DI SD MUHAMMADIYAH KLECO 1 YOGYAKARTA
}

\author{
Siti Aminah, Fitri Yuliawati
}

UIN Sunan Kalijaga Yogyakarta

Email: aamaminah976@gmail.com, fitriyulia50@gmail.com

\begin{abstract}
ABSTRAK
Kemampuan membaca siswa di sekolah tingkat sekolah dasar (SD/ MI) saat ini memiliki kecenderungan yang rendah. Berdasarkan hasil observasi yang dilakukan, peneliti menemukan permasalahan anak yang mengalami kendala terkait kemampuan membaca permulaan kelas 1 di SD Muhammadiyah Kleco 1 Yogyakarta. Salah satu upaya dalam meningkatkan kemampuan membaca permulaan yakni dengan menggunakan metode SAS. Tujuan dari penelitian ini adalah untuk mengetahui adakah pengaruh metode SAS terhadap kemampuan membaca permulaan kelas 1 di SD Muhammadiyah Kleco 1 Yogyakarta. Desain penelitian menggunakan eksperimen semu (quasi experiment) dengan pretest-posttest control group design. Populasi dalam penelitian ini seluruh siswa kelas I berjumlah 155 orang, teknik sampel menggunakan Cluster sampling. Teknik dan instrumen pengumpulan data menggunakan observasi, wawancara, dokumentasi, dan tes membaca secara lisan. Analisis data yang digunakan adalah statistik parametrik yaitu uji- $t$, dan uji normalized gain (N-gain).

Hasil penelitian menunjukan bahwa, terdapat pengaruh pembelajaran membaca permulaan menggunakan metode SAS (Struktur Analitik Sintetik), hal ini dibuktikan dengan menggunakan uji $t$ dengan pengambilan keputusan menujukan taraf signifikansi (sig. 2-tailed) $=0,000<\alpha=$ $(0,05)$, yang artinya Ha diterima sehingga terdapat perbedaan antara rata-rata kemampuan membaca permulaan kelas eksperimen dan kontrol.
\end{abstract}

AL-BIDAYAH: Jurnal Pendidikan Dasar Islam

Volume 10, Nomor 01, Juni 2018; P-ISSN: 2085-0034, E-ISSN: 2549-3388 
Peningkatan nilai $\mathrm{N}$-gain sebesar 0.83 dengan klasifikasi tinggi. Hal ini membuktikan penggunaan Metode SAS (Struktur Analitik Sintetik) dapat mempengaruhi peningkatan kemampuan membaca permulaan.

\section{Kata kunci: Metode SAS, dan Kemampuan Membaca Permulaan.}

\section{ABSTRACT}

Reading skills of students in primary level schools (SD/MI) currently has a low inclination. Based on the observations made, the researchers found children who experienced problems related constraints beginning reading skills in elementary grade 1 Muhammadiyah Kleco 1 Yogyakarta. One of the efforts to improve the ability to read the beginning of using the method of SAS. The purpose of this research is to know is there any influence of method of SAS against the ability to read the beginning of grade 1 in elementary school Muhammadiyah Kleco 1 Yogyakarta. Design research using artificial experiments (quasi experiment) with a pretest-posttest control group design. The population in this research the entire grade 1 amounted to 155 people, engineering samples using Cluster sampling. Techniques and instruments of data collection using observation, interviewing, documentation, and test reading orally. The analysis of the data used is statistical parametric i.e. test-t, normalized and test gain ( $N$-gain).

Research results show that, there is the influence of learning to read the beginning of the method using SAS (Synthetic Analytic Structure), This is proved by using the t-test with significance level addresses decision making (sig 2-tailed) $=0.000<(=(0.05)$, meaning there are accepted so that the Ha is the difference between average reading skills beginning classes and experiments controls. The increase in the value of the $\mathrm{N}$-gain of 0.83 with high classifications. This proves the use of methods of SAS (Synthetic Analytic Structure) can affect the capacity to read the beginning.

Keywords: method of SAS, and the ability to read the beginning. 


\section{A. PENDAHULUAN}

Membaca merupakan salah satu jenis kegiatan atau proses kognitif yang berupaya untuk menemukan berbagai informasi yang terdapat dalam tulisan. Membaca juga merupakan sebuah kebutuhan bagi kita, di samping ha-hal yang diperlukan untuk hidup, membaca merupakan salah satu keterampilan berbahasa. Oleh sebab itu membaca bukan hanya sekedar melihat kumpulan huruf yang telah berbentuk kata, kelompok kata, kalimat, pragraf, dan wacana saja, tetapi lebih dari itu bahwa membaca merupakan kegiatan memahami dan menginterpretasikan lambang atau tanda atau tulisan yang bermakna sehingga pesan yang disampaikan penulis dapat diterima oleh pembaca. ${ }^{1}$ Pembelajaran membaca sangat diperlukan bagi setiap orang.

Kemampuan membaca yang diperoleh pada pembaca membaca permulaan sangat berpengaruh terhadap kemampuan membaca lanjut. Sebagai kemampuan yang mendasari kemampuan berikutnya maka kemampuan membaca permulaan benar-benar memelukan perhatian guru, sebab jika dasar itu tidak kuat, pada tahap membaca lanjutan anak akan mengalami kesulitan untuk dapat memiliki kemampuan membaca yang memadai. ${ }^{2}$

Kemampuan membaca permulaan perlu dimiliki oleh setiap siswa karena dalam proses belajar akan melibatkan kegiatan membaca. Jika siswa mengalami kendala dalam membaca maka hal ini mempengaruhi pula proses keberhasilan dalam belajar, selain itu akan menghambat proses akademik karena siswa lambat dalam menangkap informasi bahkan akan kesulitan dalam mengerjakan setiap tugas yang diberikan oleh guru. Oleh karena itu perlu adanya upaya untuk meningkatkan kemampuan membaca permulaan pada siswa yang mengalami kendala dalam membaca.

Kemampuan membaca siswa di sekolah tingkat sekolah dasar atau madrasah ibtidaiyah (SD/MI) saat ini memiliki kecenderungan yang rendah. Hasil penelitian internasional, Programme for International Student Assessment (PISA) tahun 2015 tentang kemampuan membaca siswa juga menyebutkan bahwa kemampuan membaca siswa di Indonesia menduduki urutan ke-69 dari 76 negara yang disurvei. Hasil itu lebih rendah dari Vietnam yang menduduki urutan ke-12 dari total negara

1. Dalman, Keterampilan Membaca (Jakarta: Rajawali Pers, 2014), hlm. 5.

2. Nurul Hidayah dan Novita Novita, "Peningkatkan Kemampuan Membaca Permulaan Dengan Menggunakan Metode Struktur Analitik Sintetik (SAS) Mata Pelajaran Bahasa Indonesia Pada Peserta Didik Kelas II C Semester II DI MIN 6 Bandar Lampung T.A 2015/2016", Terampil: Jurnal Pendidikan dan Pembelajaran Dasar 3, no. 1 (20 Juli 2017): 88, http://ejournal.radenintan.ac.id/index.php/terampil/article/view/1331. 
yang disurvei. kemudian berdasarkan data Bank Dunia Nomor 16369-IND dan studi IEA (International Association for the Evaluation of Education Achicievement), untuk kawasan Asia Timur, Indonesia memegang posisi terendah dengan skor 51,7, dibawah Filipina dengan skor 52,6. ${ }^{3}$

Selanjutnya berdasarkan hasil observasi yang dilakukan peneliti di SD Muhammadiyah Kleco, peneliti menemukan permasalahan terkait kemampuan membaca permulaan. Meski sudah dilakukan perbaikan dalam kegiatan membaca, akan tetapi masih terdapat siswa yang mengalami permasalahan dalam membaca. Pada kelas 1 terdapat beberapa siswa mengalami permasalahan dalam membaca permulaan. Kemudian Etik Jaryanti selaku wali kelas 1, memperjelas bahwa dari 29 siswa terdapat 15 siswa yang mengalami kendala dalam membaca permulaan. Hal ini dapat dilihat dari nilai tes ulangan harian khususnya pada mata pelajaran Indonesia yang melibatkan kegiatan membaca, sebesar 65\% dari 29 siswa yang memenuhi kriteria kelulusan minimal (KKM) yang ditetapkan yaitu 75, selebihnya $45 \%$ kurang memenuhi syarat kriteria kelulusan minimal (KKM). Dari permasalahan tersebut tentunya akan menjadi kendala dalam bidang akademik dan kenaikan siswa kepada kelas selanjutnya, karena untuk memasuki jenjang kelas atas anak harus mampu lancar dalam membaca dan menulis. Jika anak mengalami kendala dalam membaca dan menulis maka hal ini anak sulit memahami pembelajaran, terlebih jika mengerjakan tugas dan mengerjakan ujian, butuh waktu hanya untuk mengeja menggabungkan huruf. ${ }^{4}$

Hal ini tentunya perlu adanya upaya untuk memperbaiki kemampuan membaca permulaan pada anak. Salah satu metode yang digunakan dalam pembelajaran membaca permulaan yakni metode SAS. Metode SAS (Struktur analitik sintetik) adalah salah satu jenis metode yang sering Kemampuan membaca permulaan perlu dimiliki oleh setiap siswa karena dalam proses belajar akan melibatkan kegiatan membaca. Jika siswa mengalami kendala dalam membaca maka hal ini mempengaruhi pula proses keberhasilan dalam belajar, selain itu akan menghambat proses akademik karena siswa lambat dalam menangkap informasi bahkan akan kesulitan dalam mengerjakan setiap tugas yang diberikan oleh guru. Oleh karena

3. Andhika Rachmanah, "Literasi Kita dan Miskinnya Buku," User Story, 12 September 2017, https://kumparan.com/andhika-rachmanah-ayahfatimahandianipuspa/literasi-kitadan-miskinnya-buku-1505192071012.

4. Etik Jatyanti, Wawancara dengan Guru Kelas 1 SD Mujammadiyah Kleco, di Ruang Perpustakaan SD Muhammadiyah Kleco 1 Kotagede Yogyakarta, 5 November 2017. 
itu perlu adanya upaya untuk meningkatkan kemampuan membaca permulaan pada siswa yang mengalami kendala dalam membaca.

Kemampuan membaca siswa di sekolah tingkat sekolah dasar atau madrasah ibtidaiyah (SD/MI) saat ini memiliki kecenderungan yang rendah. Hasil penelitian internasional, Programme for International Student Assessment (PISA) tahun 2015 tentang kemampuan membaca siswa juga menyebutkan bahwa kemampuan membaca siswa di Indonesia menduduki urutan ke-69 dari 76 negara yang disurvei. Hasil itu lebih rendah dari Vietnam yang menduduki urutan ke-12 dari total negara yang disurvei. kemudian berdasarkan data Bank Dunia Nomor 16369-IND dan studi IEA (International Association for the Evaluation of Education Achicievement), untuk kawasan Asia Timur, Indonesia memegang posisi terendah dengan skor 51,7, dibawah Filipina dengan skor 52,6. ${ }^{5}$

Selanjutnya berdasarkan hasil observasi yang dilakukan peneliti di SD Muhammadiyah Kleco, peneliti menemukan permasalahan terkait kemampuan membaca permulaan. Meski sudah dilakukan perbaikan dalam kegiatan membaca, akan tetapi masih terdapat siswa yang mengalami permasalahan dalam membaca. Pada kelas 1 terdapat beberapa siswa mengalami permasalahan dalam membaca permulaan. Kemudian Etik Jaryanti selaku wali kelas 1, memperjelas bahwa dari 29 siswa terdapat 15 siswa yang mengalami kendala dalam membaca permulaan. Hal ini dapat dilihat dari nilai tes ulangan harian khususnya pada mata pelajaran Indonesia yang melibatkan kegiatan membaca, sebesar 65\% dari 29 siswa yang memenuhi kriteria kelulusan minimal (KKM) yang ditetapkan yaitu 75 , selebihnya $45 \%$ kurang memenuhi syarat kriteria kelulusan minimal (KKM). Dari permasalahan tersebut tentunya akan menjadi kendala dalam bidang akademik dan kenaikan siswa kepada kelas selanjutnya, karena untuk memasuki jenjang kelas atas anak harus mampu lancar dalam membaca dan menulis. Jika anak mengalami kendala dalam membaca dan menulis maka hal ini anak sulit memahami pembelajaran, terlebih jika mengerjakan tugas dan mengerjakan ujian, butuh waktu hanya untuk mengeja menggabungkan huruf. ${ }^{6}$

Hal tersebut tentu perlu adanya upaya untuk memperbaiki kemampuan membaca permulaan pada anak. Salah satu metode yang digunakan dalam pembelajaran

5. Rachmanah, "Literasi Kita dan Miskinnya Buku."

6. Jatyanti, Wawancara dengan Guru Kelas 1 SD Mujammadiyah Kleco, di Ruang Perpustakaan SD Muhammadiyah Kleco 1 Kotagede Yogyakarta. 
membaca permulaan yakni metode SAS. Metode SAS (Struktur analitik sintetik) adalah salah satu jenis metode yang sering digunakan untuk membaca menulis permulaan bagi siswa pemula. Oleh karena itu penggunaan metode SAS dalam pembelajaran membaca permulaan pada sekolah-sekolah di tingkat SD pernah dianjurakan, bahkan diwajibkan oleh pemerintah. ${ }^{7}$ Dalam proses operasionalnya metode SAS mempunyai langkah-langkah struktural menampilkan kalimat secara keseluruhan, analitik menguraikan kalimat dari susunan kalimat hingga komponen terkecil yaitu bentuk huruf. ${ }^{8}$

Metode SAS (Struktur Analisis Sintetik) dapat merangsang anak didik untuk melibatkan diri secara aktif, karena anak didik selain medengarkan, melafalkan dan mecatat, juga mempergunakan alat peraga. Selain itu pola pengajaran metode SAS (Struktur Analisis Sintetik) dilakukan secara terstruktur sehingga memudahkan anak dalam menangkap pembelajaran. ${ }^{9}$

Berdasarkan analisis di atas, masalah yang ingin diangkat dalam penelitian ini sebagai berikut: "Adakah Pengaruh Metode Struktur Analitik Sistetik (SAS) Terhadap Kemampuan Membaca Permulaan Kelas I di SD Muhammadiyah Kleco 1 Yogyakarta?" Tujuan yang ingin dicapai dalam penelitian ini adalah dengan menerapkan metode SAS dapat meningkatkan kemampuan membaca permulaan dan memperbaiki dalam belajar akademik.

\section{B. KEMAMPUAN MEMBACA}

Kemampuan adalah kesanggupan seseorang untuk dapat melakukan sesuatu dengan baik dan terampil. ${ }^{10}$ Dalman mengatakan bahwa, kemampuan membaca adalah kecepatan membaca dan memahami isi, maka untuk mengetahui tingkat kemampuan membaca seseorang perlu diukur baik dengan mengatur irama kecepatan membaca, maupun mampu menjawab sekurang-kurangnya $60 \%$ dari bahan yang dibaca. ${ }^{11}$

7. T.W. Solchan, dkk., Pendidikan Bahasa Indonesia di SD, 20 ed. (Tangerang Selatan: Universitas Terbuka, 2014), hlm. 6.23.

8. Ibid.,hlm. 6.22.

9. Maguna Eliastuti dan Nur Irwansyah, "Keefektifan Membaca Menggunakan Metode Struktural Analitik Sintetik (SAS) Pada Siswa Yang Kesulitan Membaca," Deiksis 10, no. 01 (9 Maret 2018): 36, http://journal.lppmunindra.ac.id/index.php/Deiksis/article/ view/2265.

10. Tim Penyusun Kamus Pusat Bahasa, Kamus Besar Bahasa Indonesia (Jakarta: Balai Pustaka, 2002), hlm. 707.

11. Dalman, Keterampilan Membaca...,hlm. 46.

6 AL-BIDAYAH, Volume 10, Nomor 01, Juni 2018 


\section{TAHAP PERKEMBANGAN MEMBACA ANAK USIA DINI}

Dalam pemerolehan bahasa menuju tahapan membaca anak tidaklah tiba-tiba, tidak pula secara langsung, akan tetapi secara bertahap sesuai dengan perkembangan kemampuan berbahasa mereka berjalan seiring dengan perkembangan fisik, mental, intelektual, dan sosialnya.

Berikut ini tahap-tahap perolehan bahasa menuju tahap membaca: ${ }^{12}$

1. Usia 3 bulan anak mulai mengenal suara manusia ingatan yang sederhana mungkin sudah ada, tetapi belum tempak. Segala sesuatu masih terkait dengan apa yang dilihatnya. Koordinasi antara pengertian dan apa yang diucapkannya belum jelas. Anak mulai tersenyum dan mulai membuat suara-suara yang belum teratur.

2. Usia 6 bulan anak mulai bisa membedakan antara yang halus dan nada kasar, anak mulai bisa membuat vokal.

3. Usia 9 bulan anak mulai beraksi terhadap isyarat, anak mulai mengucapkan bermacam-macam suara dan tidak jarang kita bisa mendengar kombinasi suara menurut yang menurut orang dewasa suara yang aneh.

4. Usia 12 bulan anak mulai membuat reaksi terhadap perintah, anak gemar mengeluarkan suara-suara dan bisa diamati, adanya beberapa kata tertentu yang diucapkan untuk mendapatkan sesuatu.

5. Usia 18 bulan anak mulai mengukuti petunjuk, kosakatanya sudah menacapai sekitar dua puluh.

6. Usia 2-3 tahun anak sudah bisa memahami pertanyaan dan perintah sederhana.

7. Usia 4-5 tahun pemahan anak makin mantap, Anak mulai belajar berhitung dan kalimat-kalimat yang agak rumit mulai digunakan.

8. Usia 6-8 tidak ada kesukaran untuk memahami kalimat yang biasa dipakai orang dewasa sehari-hari, mulai belajar membaca dan aktifitas ini dengan sendirinya menambah perbendaharaan katanya. Mulai membiasakan diri dengan pola kalimat yang agak rumit dan bahasa 1 sudah dikuasainya sebagai alat untuk berkomunikasi. Jadi dapat disimpulkana bahwa pada saat usia 5-6 tahun anak mulai memasuki tahap usia sekolah, pada usia tersebut anak diharapkan sudah mampu untuk menguasai banyak kosa kata. Dalam memperbanyak penguasaan kosa kata mampu melalui teks bacaan, hal ini tentunya harus diajarkan melalui pembelajaran membaca permulaan.

12. Iskandar Wassid dan Dadang Sunendar, Strategi Pembelajaran bahasa (Bandung: Remaja Rosdakarya, 2016), hlm.85-86. 


\section{MEMBACA PERMULAAN}

Setiap orang yang akan belajar membaca terlebih dahulu memasuki tahap membaca permulaan. Tahap ini merupakan tahap awal dalam belajar membaca. Membaca permulaan merupakan suatu keterampilan yang harus dipelajari serta dikuasai oleh pembaca. Pada tahap membaca permuaan, anak diperkenalkan dengan bentuk huruf abjad A sampai Z, kemudian huruf-huruf tersebut dilafalkan dan dihafalkan sesuai dengan bunyinya. ${ }^{13}$

Membaca permulaan diberikan di kelas rendah (SD), yaitu dikelas satu sampai dikelas tiga. Di sinilah anak-anak harus dilatih agar mampu membaca dengan lancar sebelum mereka memasuki membaca lanjutan atau membaca pemahaman. Dalam membaca permulaan atau mekanik anak perlu dilatih dengan pelafalan yang benar dan intonasi yang tepat. ${ }^{14}$

Kemampuan membaca permulaan perlu dimiliki oleh setiap siswa sekolah dasar untuk menuju tahap kemampuan membaca lanjutan, berikut ini merupakan aspek kemampuan membaca permulaan dikelas rendah yang perlu dikuasai mencakup Pengenalan bentuk huruf, Pengenalan unsur-unsur linguistik (foem/ grafem. kata, frase, pola klausa, kalimat dan lain-lain.), kecepatan membaca ke taraf lambat. ${ }^{15}$

Dalam mencapai keberhasilan membaca permulaan hal ini tentu banyak faktor yang akan mendukung keberhasulan siswa dalam belalajar. Faktor yang mempengaruhi kemampuan membaca permulaan menurut Lamb dan Arnold dalam Hidayah ialah faktor fisiologis, intelektual, lingkungan, dan psikologis. ${ }^{16}$ Tujuan membaca permulaan adalah memberikan kecakapan kepada para peserta didik untuk mengubah rangkaian-rangkaian huruf menjadi rangkaian-rangkaian bunyi bermakna, dan melancarkan teknik membaca pada anak-anak. ${ }^{17}$ Adapun metode membaca

13. Dalman, Keterampilan Membaca..., hlm. 85.

14. Ibid., hlm. 86.

15. Abdul Chaer, Kesantunan Berbahasa (Jakarta: Rineka Cipta, 2010), hlm. 12.

16. Hidayah dan Novita, "Peningkatkan Kemampuan Membaca Permulaan Dengan Menggunakan Metode Struktur Analitik Sintetik (SAS) Mata Pelajaran Bahasa Indonesia Pada Peserta Didik Kelas II C Semester II DI MIN 6 Bandar Lampung T.A 2015/2016," 88-89.

17. Munawaroh Eprilia Aminah dan Ana Fitrotun Nisa, "Strategi Mengusik (Mengeja dengan Musik) Sebagai Cara Cepat Belajar," Albidayah: Jurnal Pendidikan Dasar Islam 8, no. 2 (2016): 189. 
dasar (permulaan) ada lima yaitu, metode eja, metode bunyi (spell method), metode lembaga kata, metode global, metode strukur analisis sintetik (SAS). ${ }^{18}$

\section{E. Metode Struktur Analisis Sintetik (SAS)}

Metode Struktur Analisis Sintesis (SAS) merupakan pengajaran membaca dan menulis di Sekolah Dasar. Dalam proses operasionalnya, metode SAS mempunyai langkah-langkah dengan urutan (a) strukutur, menampilkan keseluruhan, (b) analisis, melakukan proses peng-uraian, (c) sintesis, melakukan penggabungan kembali pada struktur semula. ${ }^{19}$

Penguraian atau penganalisisan dalam pembelajaran membaca permulaan dengan menggunakan metode SAS, meliputi: ${ }^{20}$ (1) kalimat menjadi kata-kata, (2) kata menjadi suku-suku kata, dan (3) suku kata menjadi huruf. Metode Struktur Analisis Sintesis (SAS) dilandasi oleh prinsip-prinsip hasil penelitian ilmu bahasa (linguistik), ilmu jiwa, ilmu filsafat, dan ilmu pendidikan. ${ }^{21}$ Metode ini mempertimbangkan pengalaman berbahasa anak, oleh karena itu, pembelajaran akan lebih bermakna bagi anak karena bertolak dari sesuatu yang dikenal dan diketahui anak. Hal ini akan memberikan dampak positif terhadap daya ingat dan pemahaman anak. Metode ini sesuai dengan prinsip inkuiri (menemukan sendiri). Anak mengenal dan memahami sesuatu berdasarkan hasil temuannya sendiri. Sikap seperti ini akan membantu anak dalam mencapai keberhasilan belajar. ${ }^{22}$

Berdasarkan analisis di atas metode SAS merupakan sebuah metode yang diperuntukan khusus bagi siswa yang baru belajar membaca. Proses operasional metode SAS diawali dengan menampilkan struktur kalimat yang utuh, kemudian dilanjutkan pada analitik dari kalimat diuraikan menjadi kata, kata menjadi suku

\section{Ibid.,hlm. 189-190.}

19. Eliastuti dan Irwansyah, "Keefektifan Membaca Menggunakan Metode Struktural Analitik Sintetik (SAS) Pada Siswa Yang Kesulitan Membaca,” 35.

20. Ibid.,hlm. 35

21. Slamet, Dasar-Dasar Pembelajaran Bahasa dan Sastra Indonesia Disekolah Dasar (Surakarta, Jawa Tengah: Lembaga Pengembangan Pendidikan (LPP) UNS dan UPT UNS Press, 2007), hlm. 65-66.

22. Otang Kurniaman dan Eddy Noviana, "Metode Membaca Sas (Struktural Analitik Sintetik)Dalam Meningkatkan Keterampilan Membaca Permulaandi Kelas I SDN 79 Pekanbaru," Primary: Jurnal Pendidikan Guru Sekolah Dasar 5, no. 2 (13 Desember 2016): 152, https://ejournal.unri.ac.id/index.php/JPFKIP/article/view/3705. 
kata, kata diuraikan menjadi struktrur terkecil yakni huruf, pada tahap terakhir proses sintetik yakni mengubah bentuk semula menjadi kalimat yang utuh. Pembelajaran ini tujuannya yakni agar anak mampu menemukan sendiri sehingga anak akan mampu mudah mengingat dan menjadi lebih bermakna dalam belajar.

\section{F. METODE PENELITIAN}

Pendekatan penelitian yang digunakan dalam penelitian ini adalah pendekatan kuantitatif dengan jenis penelitian eksperimen semu (Nonequivalent Control Group Design. Populasi yang berjumlah 115 siswa. Sampel penelitian ditentukan menggunakan teknik Cluster sampling yang terpilih 57 siswa. Sampel penelitian yang terpilih adalah kelas I Sidiq sebagai kelas eskperimen dan I Fatonah sebagai kelas kontrol. Teknik pengumpulan data yang digunakan adalah observasi, wawancara dokumentasi, dan pretest-posttest kemampuan membaca permulaan secara lisan. Analisis data menggunakan Uji prasyarat analisis untuk menentukan kedua sampel yakni uji normalitas dan homogenitas menggunakan spss 16.0. Hal ini dilakukan untuk mengetahui sampel apakah normal dan homogen. Jika kedua sampel tersebut normal dan homogen maka peneliti dapat menggunakan uji $t$ statistik parametrik, namun jika keduanya tidak normal dan homogen maka menggunakan statistik non parametrik. Setelah dilakukan $u j i t$ dengan pengujian dua sisi antara kelompok eksperimen dan kontrol untuk mengetahui perbedaan setelah melakukan penerapan metode SAS, selanjutnya melakukan uji N-Gain. Hal ini untuk mengetahui besar sumbangan yang diberikan sehingga dapat dilihat besar pengaruh dari metode SAS.

\section{G. HASIL PENELITIAN DAN PEMBAHASAN}

Penelitian ini meliputi tiga tahapan, yakni pre-test, perlakuan (treatment), dan post-test. Tahapan pertama pertama kedua kelas diberikan pre-test, kemudian masing-masing kelas diberikan perlakuan yang berbeda, kelas kontrol diberikan metode konvensional sedangkan kelas eksperimen diberikan materi dengan metode SAS (Struktur Analitik Sintetik) dilengkapi dengan media gambar dan karu huruf, terakhir kemudian diberikan post-test.

Sampel penelitian ini adalah kelas 1 Sidiq sebagai kelas eksperimen dan kelas 1 Fathonah sebagai kelas kontrol. Berikut ini hasil pretest-postest yang dilakukan pada kelas kelas 1 Sidiq dan kelas 1 Fathonah adalah sebagai berikut: 


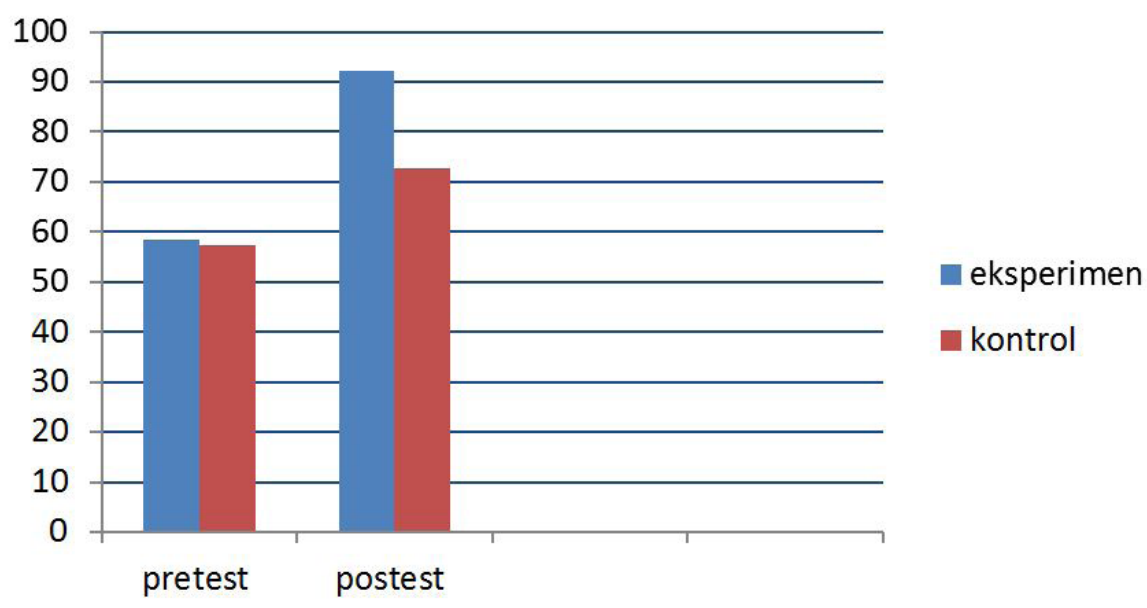

Gambar 1. Peningkatan Nilai Pretest-Posttest

Berdasarkan data di atas tes kemampuan membaca permulaan yang berupa tes membaca secara lisan diperoleh hasil bahwa kenaikan nilai pre-test dan post-test kelas eksperimen yang mendapatkan perlakuan (treatment) menggunakan metode sas jauh lebih tinggi dibandingkan kelas kontrol yang tidak mendapat perlakuan (treatment). Pada kelas eksperiem semula rata-rata skor pretes adalah 58,86, kemudian pada saat posstest naik menjadi 92,83. Pada kelas kontrol semula rata-rata skor pretes adalah 57,43 kemudian pada saat posstest naik menjadi 72,43. Melihat dari hasil nilai ratarata kelas eksperimen atau kontrol kedua sama-sama mengalami peningkatan, akan tetapi nilai rat-rata kelas eksperimen jauh lebih tinggi dibandingkan kelas kontrol.

Kemudian untuk mengetahui perbedaan kedua kelompok maka harus malakukan uji hipotesis atau pengambilan keputusan. Dalam menentukan keputusan apakah menggunakan statistik parametrik atau non parametrik maka dibutuhkan uji prasyarat. Uji prasyarat dalam penentuan analisis ini meliputi uji normalitas dan homogenitas, berikut ini hasil uji prasyarat analisis hasil normalitas dan homogenitas pretestpostest kelas eksperimen dan kelas kontrol:

Tabel. 1 Hasil Uji Normalitas dan Homogenitas Pretest-Postest Kelas Ekperimen dan Kontrol

\begin{tabular}{lccccc}
\hline Kelas & Pretest & Pretest & Pretest & Pretest & Keterangan \\
\cline { 2 - 3 } & $\begin{array}{c}\text { Kolmogorov } \\
\text { Smirnov }\end{array}$ & Sig.Uji Levene & $\begin{array}{c}\text { Normal } \\
\text { Homogen }\end{array}$ \\
\hline Eksperimen & 0.067 & 0.103 & 0.599 & 0.127 & $\begin{array}{c}\text { Normal } \\
\text { Homogen }\end{array}$ \\
\hline Kontrol & 0.066 & 0.209 & & &
\end{tabular}


Berdasarkan tabel 1 di atas hasil uji normalitas Pretest - Posttest memiliki nilai sig. $>0,05$. Hasil perhitungan skor pretest diketahui nilai sig pada kelas eksperimen 0.067, pada kelas kontrol 0.066. dan untuk skor Posttest pada kelas eksperimen 0.103, sedangkan kelas kontrol 0.209. keduanya lebih besar dari 0.05 , maka dapat disimpulkan kedua hasil Pretest - Posttest baik kelas eksperimen dan kelas kontrol berdistribusi normal. Kemudian perhitungan Pretest uji homogenitas kemampuan membaca permulaan sebesar 0,599, kemudian hasil Posttest sebesar 0.127. Nilai tersebut lebih besar dari nilai sig $<0,05$ sehingga kedua kelas tersebut dikatakan homogen.

Setelah dilakukan uji prasyarat analisis yakni uji normalita dan uji homogenitas diketahui kedua data tersebut normal dan homogeny langkah selanjutnya yakni melakuan uji $t$ melalui software SPSS 16.0. Penelitian ini menggunakan komparasi dua sampel independen (tidak berkorelasi). Uji $t$ digunakan untuk mengetahui apakah terdapat perbedaan rata-rata statistik antara kelas eksperimen dan kelas kontrol setelah diberikan perlakuan. Berikut ini hasil uji $t$ dua pihak sampel independen, hipotesis yang diajukan dalam pengujian ini adalah sebagai berikut:

$\mathrm{H}_{0}=$ Tidak ada perbedaan pengaruh metode struktur analitik sintetik terhadap rata-rata kemampuan membaca permulaan pada kelas eksperimen dan kelas kontrol

$\mathrm{H}_{\alpha}=$ Terdapat perbedaan pengaruh metode struktur analitik sintetik terhadap kemampuan membaca permulaan pada kelas eksperimen dan kelas kontrol.

- Jika nilai sig $>0,05$ maka Ho diterima

- Jika nilai $\operatorname{sig}<0,05$ maka Ho ditolak

Berikut ini hasil uji t Independen Sampel t- test:

Tabel 2. Hasil Uji $t$

\begin{tabular}{lccc}
\hline Kelas & Pretest & Posttest & keterangan \\
& (t-test for equality of mean $)$ & \\
\cline { 1 - 2 } Eksperimen & 0.642 & 0.000 & Tidak berbeda \\
\cline { 1 - 1 } kontrol & & & berbeda \\
\hline
\end{tabular}

Berdasarkan hasil perhitungan, diketahui nilai sig uji Independen pada nilai pretest bahawa sig.(2-tiled) sebesar 0.642 untuk kelas eksperimen dan untuk kelas kontrol. Nilai tersebut lebih besar dari 0,05 sehingga $H_{o}$ diterima, bahwa dapat 
diketahui tidak ada perbedaan rata-rata kemampuan awal siswa kelas eksperimen dan kontrol sebelum diberikan treatmet adalah sama.

Selanjutnya hasil perhitungan, bahwa diketahui nilai sig uji Independen Pada nilai posttest berdasarkan tabel 2 didapat nilai sig. (2-tiled) sebesar 0.000 pada kelas eksperimen dan kelas kontrol, nilai tersebut lebih kecil dari taraf signifikasi 0.05 Ho ditolak sehingga dapat diambil kesimpulan bahwa terdapat perbedaan rata-rata kemampuan membaca permulaan pada siswa kelas eksperimen dan kelas kontrol adalah berbeda setelah diberikan perlakuan (treatmen). Sehingga dapat disimpulakan bahwa penerapan metode SAS (Struktur Analitik Sintetik) dapat mempengaruhi kemampuan membaca permulaan pada siswa.

Kemudian hasil uji $\mathrm{N}$-Gain skor pretest dan posttest antara kelas eksperimen dan kontrol dalam peningkatan kemampuan membaca permulaan dapat dilihat dari analisis tabel berikut:

Tabel 3. Hasil Uji N-Gain Kemampuan Membaca Permulaan

\begin{tabular}{lccccc}
\hline Kelas & $\mathrm{N}$ & $\begin{array}{c}\text { Rata-rata } \\
\text { Pretest }\end{array}$ & $\begin{array}{c}\text { Rata-rata } \\
\text { Posttest }\end{array}$ & N-Gain & Klasifikasi \\
\hline Eksperimen & 29 & 58.4 & 92.3 & 0.83 & Tinggi \\
\hline Kontrol & 28 & 57.3 & 72.7 & 0.36 & sedang \\
\hline
\end{tabular}

Berdasarkan tabel 3 hasil $N$-Gain kelas eksperiman dan kelas kontrok keduanya mengalami penigkatan. Penerapan pembelajaran menggunakan metode SAS (Struktur Analitik Sintetik) memberikan kontribusi lebih tinggi dibanding dengan metode konvensional. Pada kelas eksperimen mengalami peningkatan sebesar 0.83 dengan klasifikasi tinggi sedangkan pada kelas kontrol sebesar 0.36 klasifikasi sedang.

Melihat dari data di atas berdasarkan uji t Independen bahwa terdapat perbedaan yang sangat signifikan antara kelas yang menggunakan metode SAS dan tanpa menggunakan metode SAS. Kemudian hasil $N$-Gain menunjukan penerapan pengguanaan metode SAS sangat mempengaruhi peningkatakan kemampuan membaca permulaan pada siswa dengan dilihat dari nilai hasil rata-rata kelas eksperimen dan kontrol.

Penggunaan metode SAS (Struktrur Analitik Sintetik) sesuai dengan prinsip linguistik yakni mempertimbangkan pengalaman berbahasa anak, oleh karena itu pengajaran bermakna bagi siswa, kemudian sesuai dengan yang dikenal dan diketahui anak. Hal ini memberi dampak positif terhadap daya ingat dan pemahaman anak. 
Selain itu metode sesuai SAS (Struktrur Analitik Sintetik) dengan prinsip inkuiri (menemukan sendiri). Siswa mengenal dan memahami sesuatu berdasarkan hasil temuannya sendiri. Sikap seperti ini akan membantu siswa berpikir untuk menumbuh kembangkan cara berpikir logis akan merasa lebih percaya diri atas kemampuannnya sendiri serta siswa dalam mencapai keberhasilan belajar. ${ }^{23}$ Penggunanaan metode SAS (Struktrur Analitik Sintetik) juga sesuai dengan landasan pedagogis meliputi: (1) mendidik adalah membantu siswa untuk mengembangkan potensi yang ada dalam dirinya serta pengalamannya. (2) membimbing murid untuk menemukan jawaban dalam memecahkan masalah. Hal ini sejalan dengan prinsip metode SAS yang mengemukakan bahwa mendidik pada dasarnya mengorganisasikan potensi dan pengalaman siswa. ${ }^{24}$

\section{H. KESIMPULAN}

Berdasarkan uraian pembahasan di atas dapat ditarik kesimpulan sebagai berikut:

1. Terdapat pengaruh pada penerapan metode (SAS) Struktur Analitik Sintetik dibandingkan dengan menggunakan metode konvensional biasa. Hal ini dengan pembuktian yang dilakukan melalui uji t independent yang menunjukan nilai (sig. 2 tailed) sebesar 0,000 lebih kecil dari 0,05 yang memberikan arti bahwa terdapat perbedaan kemampuan membaca permulaan ketika sebelum diberikan treament dan sesudah diberikan treatment, dengan nilai $\mathrm{N}$-gain 0,83 memiliki arti dapat meningkatkan kemampuan membaca permulaan, termasuk kategori tinggi karena di atas 0.7

2. Pembelajaran membaca permulaan menggunakan metode (SAS) Striktur Analitik Sintetik membuat anak tertarik dan antusian dalam proses belajar membaca, karena mereka tidak mudah jenuh dengan kegiatan merangkai huruf, untuk menjadi sebuah kalimat yang utuh sehingga menjadi sesuatu yang bermakna. Hal ini pula meningkatkan daya ingat anak karena melibatkan proses inkuiri (menemukan sendiri).

23. T.W. Solchan, dkk., Pendidikan Bahasa Indonesia..., hlm. 6.23.

24. Slamet, Dasar-Dasar Pembelajaran Bahasa..., hlm. 65-66. 


\section{DAFTAR PUSTAKA}

Aminah, Munawaroh Eprilia, dan Ana Fitrotun Nisa. "Strategi Mengusik (Mengeja dengan Musik) Sebagai Cara Cepat Belajar." Albidayah: Jurnal Pendidikan Dasar Islam 8, no. 2 (2016): 180-95.

Chaer, Abdul. Kesantunan Berbahasa. Jakarta: Rineka Cipta, 2010.

Dalman. Keterampilan Membaca. Jakarta: Rajawali Pers, 2014.

Eliastuti, Maguna, dan Nur Irwansyah. "Keefektifan Membaca Menggunakan Metode Struktural Analitik Sintetik (SAS) Pada Siswa Yang Kesulitan Membaca." Deiksis 10, no. 01 (9 Maret 2018): 33-42. http://journal.lppmunindra.ac.id/ index.php/Deiksis/article/view/2265.

Hidayah, Nurul, dan Novita Novita. "PENINGKATKAN KEMAMPUAN MEMBACA PERMULAAN DENGAN MENGGUNAKAN METODE STRUKTUR ANALITIK SINTETIK (SAS) MATA PELAJARAN BAHASA INDONESIA PADA PESERTA DIDIK KELAS II C SEMESTER II DI MIN 6 BANDAR LAMPUNG T.A 2015/2016." Terampil: Jurnal Pendidikan dan Pembelajaran Dasar 3, no. 1 (20 Juli 2017): 85-102. http://ejournal. radenintan.ac.id/index.php/terampil/article/view/1331.

Jatyanti, Etik. Wawancara dengan Guru Kelas 1 SD Mujammadiyah Kleco, di Ruang Perpustakaan SD Muhammadiyah Kleco 1 Kotagede Yogyakarta, 5 November 2017.

Kurniaman, Otang, dan Eddy Noviana. "METODE MEMBACA SAS (STRUKTURAL ANALITIK SINTETIK) DALAM MENINGKATKAN KETERAMPILAN MEMBACA PERMULAAN DI KELAS I SDN 79 PEKANBARU." Primary: Jurnal Pendidikan Guru Sekolah Dasar 5, no. 2 (13 Desember 2016): 149-57. https://ejournal.unri.ac.id/index.php/JPFKIP/ article/view/3705.

Rachmanah, Andhika. "Literasi Kita dan Miskinnya Buku.” User Story, 12 September 2017. https://kumparan.com/andhika-rachmanah-ayahfatimahandianipuspa/ literasi-kita-dan-miskinnya-buku-1505192071012.

Slamet. Dasar-Dasar Pembelajaran Bahasa dan Sastra Indonesia Disekolah Dasar. Surakarta, Jawa Tengah: Lembaga Pengembangan Pendidikan (LPP) UNS dan UPT UNS Press, 2007. 
Siti Aminah, Fitri Yuliawati

Solchan, dkk., T.W. Pendidikan Bahasa Indonesia di SD. 20 ed. Tangerang Selatan: Universitas Terbuka, 2014.

Tim Penyusun Kamus Pusat Bahasa. Kamus Besar Bahasa Indonesia. Jakarta: Balai Pustaka, 2002.

Wassid, Iskandar, dan Dadang Sunendar. Strategi Pembelajaran bahasa. Bandung: Remaja Rosdakarya, 2016.

16 AL-BIDAYAH, Volume 10, Nomor 01, Juni 2018 